\title{
Properties of Biodegradable Alloys Usable for Medical Purposes
}

\author{
J. KubÁSEK*, D. VOJTĚCH AND J. ČAPEK \\ Department of Metals and Corrosion Engineering, Institute of Chemical Technology \\ Technická 5, 16628 Prague, Czech Republic
}

\begin{abstract}
Magnesium alloys are promising materials for production of biodegradable implants that may be used for fixation of fractured bones. Magnesium itself is an essential element that plays important roles in many biological processes. However, some common alloying elements of magnesium alloys such as aluminium or copper may cause health problems to the organism. A major problem is the high corrosion rate of magnesium and its alloys in physiological environment that contains chloride anions. Currently, the research focuses on alloys doped by rare-earth elements and zinc. All these elements affect corrosion resistance and mechanical properties of magnesium alloys. This work was dealing with the study of $\mathrm{Mg}-\mathrm{Gd}$ binary alloy and $\mathrm{Mg}-\mathrm{Gd}-\mathrm{Y}$, $\mathrm{Mg}-\mathrm{Gd}-\mathrm{Zn}$ ternary alloys that were prepared from pure metals by melting in induction furnace. Various alloy compositions were tested. Corrosion behaviours in $9 \mathrm{M} \mathrm{NaCl}$ saline environments (exposure tests, potentiodynamic measurements) were studied on alloys in the cast state. Good corrosion resistance and uniform corrosion were observed in the case of binary $\mathrm{Mg}-\mathrm{Gd}$ alloy. The influence of the addition of $\mathrm{Y}$ or $\mathrm{Zn}$ to the $\mathrm{Mg}-\mathrm{Gd}$ system is discussed.
\end{abstract}

PACS: 61.66.Dk, 64.70.kd

\section{Introduction}

Magnesium is a suitable candidate for the preparation of biodegradable implants due to its non-toxicity and very important role in biological processes [1-3]. Recommended dietary allowance (RDA) for adults is 300$400 \mathrm{mg} /$ day [2, 3]. A significant advantage of magnesium based alloys is the modulus of elasticity that is around $45 \mathrm{GPa}$ [1]. That is much closer to the modulus of elasticity of bones in comparison with other metal materials such as stainless steels or titanium based alloys. For example the modulus of elasticity of cortical bone is in the order of 3-20 GPa, however the stainless steel may be characterized by $200 \mathrm{GPa}$. Big differences in modulus of elasticity can lead to the stress shielding effect and negatively affect the healing process $[1,2]$.

Mechanical properties of magnesium and its alloys are closer to human bones in comparison with currently known materials. It supports good healing process $[1,2]$. However, the corrosion resistance of magnesium in physiological environment that contains especially chloride anions is quite poor. Excessive corrosion rate can lead to formation of hydrogen pockets and local alkalization which may affect the $\mathrm{pH}$-dependent physiological reaction equilibrium [2]. Both mechanical properties and corrosion behaviour may be improved by alloying with other metals ( $\mathrm{Al}, \mathrm{Mn}, \mathrm{Zn}, \mathrm{Ca}, \mathrm{RE}=$ rare-earth elements) but some of these elements may be connected with medical complications of various nature [3]. Recently, the re-

* corresponding author; e-mail: Kubasek.jiri@gmail.com search has been focused on magnesium alloys containing especially Gd, Y and $\mathrm{Zn}$ [4-8], although many results are connected more with applications in automotive industry than in medicine.

In this work corrosion behaviour of $\mathrm{Mg} 3 \mathrm{Gd}, \mathrm{Mg} 3 \mathrm{Gd} 1 \mathrm{Y}$ and Mg2Gd7Zn was examined. The influence of $\mathrm{Zn}$ or $\mathrm{Y}$ addition on structure and corrosion behaviour of binary MgGd is discussed.

\section{Experimental}

Cylindrical ingots of $\mathrm{Mg}, \mathrm{Mg} 3 \mathrm{Gd}, \mathrm{Mg} 3 \mathrm{Gd} 1 \mathrm{Y}$ and Mg2Gd7Zn were prepared by melting of pure $\mathrm{Mg}$ (99.9 wt\%), Gd (99.9 wt\%), Y (99.9 wt\%) and $\mathrm{Zn}$ (99.9 wt\%) in vacuum induction furnace under protective argon atmosphere of technical purity (99.9 wt\%). The melt was homogenized for $15 \mathrm{~min}$ at $750^{\circ} \mathrm{C}$ and casting into cast-iron metallic mould with $100 \mathrm{~mm}$ in length and $20 \mathrm{~mm}$ in diameter. These moulds were not preheated. The chemical composition of these ingots was verified in the middle of cylindrical ingot by X-ray fluorescence spectrometry (Table I). Vickers hardness with a load of $5 \mathrm{~kg}$ (HV5) was measured on samples grinded on abrasive papers P800. The microstructure of alloys was observed by light microscopy and scanning electron microscopy (Tescan Vega 3 LMU). For this purpose, the samples were grinded using $\mathrm{SiC}$ abrasive papers $\mathrm{P} 180$ $\mathrm{P} 4000$, polished by diamond pastes with 2 and $0.7 \mu \mathrm{m}$ particles and etched in $2 \mathrm{ml} \mathrm{HNO}_{3}+100 \mathrm{ml} \mathrm{H} 2 \mathrm{O}$ solution.

Phase and chemical composition were studied by energy dispersion spectrometry (Oxford Instruments Inca 
TABLE I

Chemical composition of investigated magnesium alloys (wt\%).

\begin{tabular}{c|c|c|c|c}
\hline & $\mathrm{Mg}$ & $\mathrm{Mg} 3 \mathrm{Gd}$ & $\mathrm{Mg} 3 \mathrm{GdY}$ & $\mathrm{Mg} 2 \mathrm{Gd} 7 \mathrm{Zn}$ \\
\hline $\mathrm{Mg}$ & 99.9 & 96.99 & 96.08 & 90.9 \\
$\mathrm{Gd}$ & $<0.01$ & 2.8 & 3.03 & 1.94 \\
$\mathrm{Y}$ & $<0.01$ & $<0.01$ & 0.89 & $<0.01$ \\
$\mathrm{Zn}$ & 0.01 & $<0.01$ & $<0.01$ & 6.91 \\
$\mathrm{Fe}$ & $<0.004$ & $<0.004$ & $<0.004$ & $<0.004$ \\
$\mathrm{Ni}$ & $<0.004$ & $<0.004$ & $<0.004$ & $<0.004$ \\
$\mathrm{Cu}$ & $<0.004$ & $<0.004$ & $<0.004$ & 0.11 \\
$\mathrm{Si}$ & 0.03 & $<0.01$ & $<0.01$ & 0.02 \\
$\mathrm{Al}$ & 0.04 & $<0.01$ & $<0.01$ & 0.024 \\
$\mathrm{Mn}$ & $<0.01$ & 0.03 & $<0.01$ & 0.03
\end{tabular}

350 ) and X-ray diffraction (X'Pert Philips, $30 \mathrm{~mA}, 40 \mathrm{kV}$, X-ray radiation $\mathrm{Cu} K_{\alpha}$ ). The corrosion behaviour was studied by immersion tests that were performed in aerated physiological solution $(9 \mathrm{~g} / \mathrm{l} \mathrm{NaCl})$ at initial $\mathrm{pH}=$ 6.5. Before the tests, the samples were grinded on $\mathrm{SiC}$ abrasive papers and degreased with ethanol. Samples with approximately $20 \mathrm{~mm}$ in diameter and $3 \mathrm{~mm}$ in thickness were clamped at two points in plastic mounts and immersed in a physiological solution for $336 \mathrm{~h}$ at $25^{\circ} \mathrm{C}$. The ratio of the volume of the physiological solution and surface area of the specimen was kept on the value of $36 \mathrm{ml} / \mathrm{cm}^{2}$.

After exposure tests, corrosion products were removed by pickling for $5 \mathrm{~min}$ in a solution containing $200 \mathrm{~g} / \mathrm{l}$ $\mathrm{CrO}_{3}$. Corrosion rates were calculated from weight losses after pickling in $200 \mathrm{~g} / \mathrm{l} \mathrm{CrO}_{3}$ measured with an accuracy of $0.1 \mathrm{mg}$. Moreover, potentiodynamic curves were measured with $\mathrm{SCE}(\mathrm{Ag} / \mathrm{AgCl} / \mathrm{KCl}-3 \mathrm{~mol} / \mathrm{l})$ as reference electrode and platinum wire as counter electrode from $-0.2 \mathrm{~V} /$ Eocp to $+0.8 \mathrm{~V} /$ Eocp. The scanning rate was $2 \mathrm{mV} / \mathrm{s}$. The $\mathrm{pH}$ changes were recorded during exposure experiments.

\section{Results and discussion}

\subsection{Structures and mechanical properties}

Structures of alloys with RE elements that were observed by optical microscope are displayed in Fig. 1 . These alloys were characterized by dendritic structure with substantial dendritic microsegregations. The solubility of Gd and $\mathrm{Y}$ at the eutectic temperature in binary $\mathrm{Mg}-\mathrm{Gd}$ and $\mathrm{Mg}-\mathrm{Y}$ system is 23.49 and $12.47 \mathrm{wt} \%$, respectively [9].

Although concentrations of Gd or Y in studied alloys are significantly lower in comparison with their solubility at eutectic temperature, structure of studied $\mathrm{Mg}-\mathrm{Gd}$ and $\mathrm{Mg}-\mathrm{Gd}-\mathrm{Y}$ alloys was composed of a solid solution of $\alpha-\mathrm{Mg}$ (white areas in Fig. 1) and eutectic $\mathrm{Mg}_{5} \mathrm{Gd}$ phase in the form of cuboid-shaped compounds with size in the range between 0.5 and $1 \mu \mathrm{m}$ (Fig. 2). These phases were preferentially distributed at the interface of dendrites in the areas with the highest dendritic microsegregation (dark areas in Fig. 1a, b). In both systems, 20

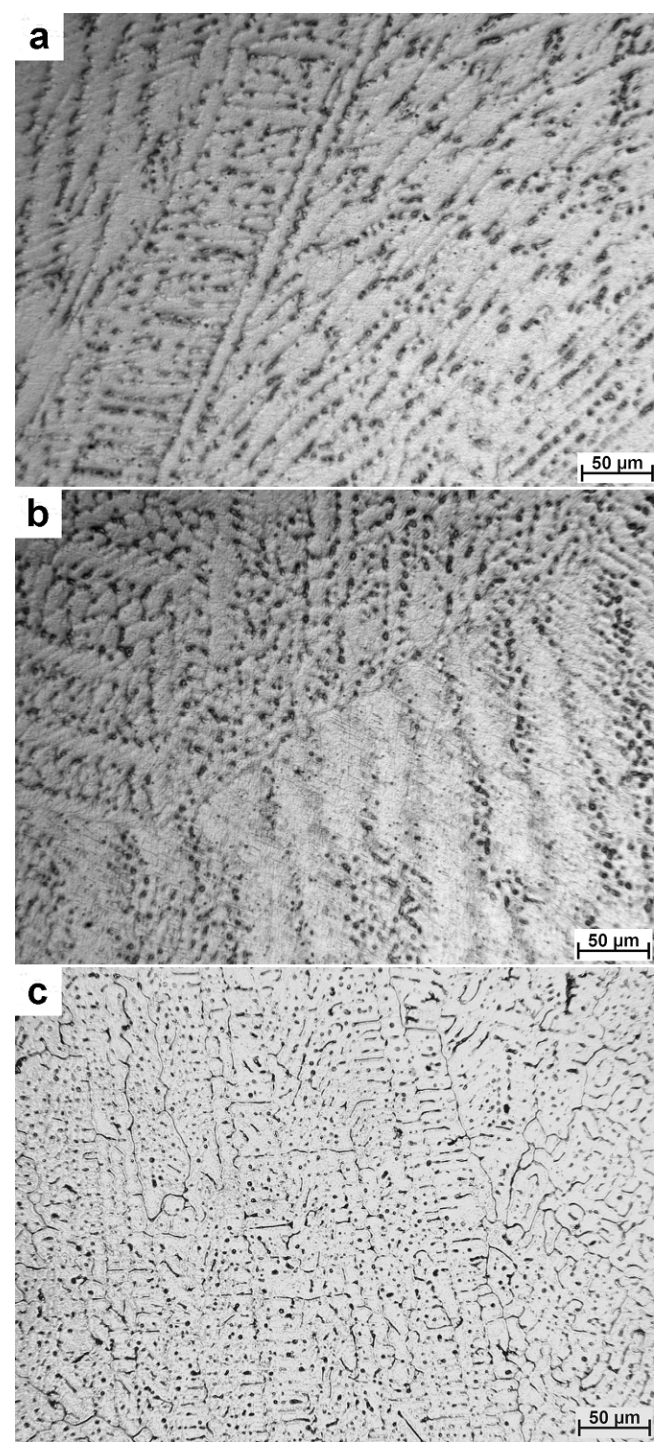

Fig. 1. Microstructure of alloys:

(a) Mg3Gd, measurements of energy dispersive spectroscopy (EDS) analyses confirmed the presence of $\mathrm{Mg}_{5} \mathrm{Gd}$ phase with average composition of $48.2 \pm 6.3 \mathrm{wt} \%$ of $\mathrm{Gd}$ for Mg5Gd and $51.6 \pm 4.9 \mathrm{wt} \%$ of $\mathrm{Gd}$ for Mg5Gd1Y. Moreover, in the case of $\mathrm{Mg}-\mathrm{Gd}-\mathrm{Y}$ system, from 2 up to $4 \mathrm{wt} \%$ of $\mathrm{Y}$ was provided in this phase. The reason for this may be in the small size of eutectic phases, so the results are influenced by composition of solid solution adjacent to $\mathrm{Mg}_{5} \mathrm{Gd}$ phases. Differences in the contents of $\mathrm{Gd}$ in $\mathrm{Mg}-\mathrm{Gd}, \mathrm{Mg}-\mathrm{Gd}-\mathrm{Y}$ solid solution due to the dendritic microsegregation were in the range from $1 \mathrm{wt} \%$ up to $4 \mathrm{wt} \%$ inside the dendrites. However, it may be assumed higher content of Gd at the interface of dendrites. These values cannot be measured directly by EDS due to the large influence of eutectic phases with higher content of Gd. Yttrium concentrations were in the range from 0.5 to $1.5 \mathrm{wt} \%$. 


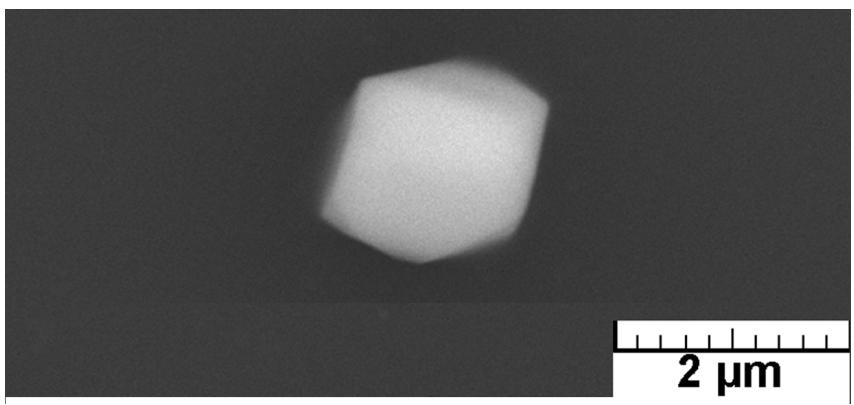

Fig. 2. $\mathrm{Mg}_{5} \mathrm{Gd}$ phase in Mg3Gd binary alloy.

The microstructure of Mg2Gd7Zn was composed of solid solution of $\alpha-\mathrm{Mg}$ (white areas in Fig. 1c), $\mathrm{Mg}_{5} \mathrm{Gd}$ and $\mathrm{Mg}-\mathrm{Gd}-\mathrm{Zn}$ ternary phase that were distributed at the interface of dendrites (black areas in Fig. 1c). Due to the interaction of $\mathrm{Zn}$ and $\mathrm{Gd}$, the solubility of these elements in matrix is decreased. It is the reason why the ternary phases are formed. Moreover, it is known that $\mathrm{Zn} / \mathrm{Y}$ or $\mathrm{Zn} / \mathrm{Gd}$ weight ratio influence the phase formation [10-12]. Zn/Gd ratio in Mg2Gd7Zn corresponds to $\mathrm{Mg}_{3} \mathrm{GdZn}_{6}$ phase (I-phase).

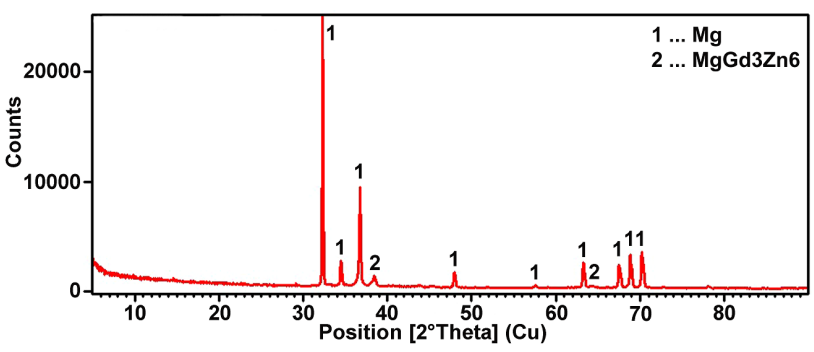

Fig. 3. I-phase in $\mathrm{Mg} 2 \mathrm{Gd} 7 \mathrm{Zn}$ alloy.

TABLE II

Vickers hardness and corrosion rate of investigated alloys.

\begin{tabular}{c|c|c|c|c}
\hline \hline & $\mathrm{Mg}$ & $\mathrm{Mg3Gd}$ & $\mathrm{Mg3GdY}$ & $\mathrm{Mg} 2 \mathrm{Gd} 7 \mathrm{Zn}$ \\
\hline $\begin{array}{c}\text { HV5 } \\
\text { corrosion } \\
\text { rate }[\mathrm{mm} / \mathrm{y}]\end{array}$ & $29.7 \pm 3$ & $42.5 \pm 2.4$ & $45.6 \pm 1.9$ & $49.8 \pm 2.6$ \\
& $3.61 \pm 0.32$ & $0.29 \pm 0.02$ & $3.20 \pm 0.38$ & $3.13 \pm 0.65$
\end{tabular}

This phase was proved by diffraction analyses (Fig. 3). Due to the obvious dendritic microsegregations it may be considered that the increase of the Vickers hardness in comparison with pure $\mathrm{Mg}$ was probably caused by solid solution strengthening and not only by the presence of intermediate phases in the structure. Average values of HV5 (Table II) were calculated from 20 measurements on the specimen.

\subsection{Corrosion behaviour}

Magnesium is a non-noble metal. It corrodes in acidic, neutral and slightly alkaline environments but in strongly alkaline environment a passive $\mathrm{Mg}(\mathrm{OH})_{2}$ layer is formed. The presence of other phases that are more noble than $\mathrm{Mg}$ may lead to microgalvanic corrosion. This kind of corrosion behaviour was described in different magnesium alloys such as AZ, AE, WE, WZ, etc. It was shown that higher amount of $\beta$ phase in structure of AZ91 alloy may act as a barrier and increase corrosion resistance. On the contrary, a lower amount of $\beta$ phase acts as a cathode and increases the corrosion rate by microgalvanic corrosion between $\alpha-\mathrm{Mg}$ and $\beta$ phase [13]. Similar behaviour may be expected in other types of magnesium alloys. Corrosion rates of $\mathrm{Mg}, \mathrm{Mg} 3 \mathrm{Gd}, \mathrm{Mg} 3 \mathrm{Gd} 1 \mathrm{Y}$ and Mg2Gd7Zn alloy are shown in Table II. It is evident that the addition of $3 \mathrm{wt} \%$ of $\mathrm{Gd}$ to pure $\mathrm{Mg}$ rapidly decreases the corrosion rate to nearly $0.29 \mathrm{~mm} / \mathrm{y}$. Although addition of $\mathrm{Y}$ and $\mathrm{Zn}$ is considered to have a positive effect on corrosion resistance of magnesium alloys, corrosion rates of $\mathrm{Mg}-\mathrm{Gd}-\mathrm{Y}$ and $\mathrm{Mg}-\mathrm{Gd}-\mathrm{Zn}$ were much higher in comparison with binary Mg3Gd. Moreover, these values were only slightly lower in comparison with the corrosion rate of pure $\mathrm{Mg}$. The reason may be attributed to higher content of intermetallic phases and more significant structure inhomogeneity as a consequence of higher concentration of alloying elements. In this case $\mathrm{Mg}_{5} \mathrm{Gd}$ phase acts as a cathode while $\alpha-\mathrm{Mg}$ is preferentially dissolved due to the anodic process. Corrosion reaction is spread especially from the interface between solid solution and intermetallic phases. Due to the dissolution of matrix, intermetallic phases may be released from the surface. In Mg2Gd7Zn alloy, $I$-phase is considered to have bad effect on corrosion resistance of $\mathrm{Mg}-\mathrm{Y}-\mathrm{Zn}$ or $\mathrm{Mg}-\mathrm{Gd}-\mathrm{Zn}$ alloys [10, 11]. It is evident from potentiodynamic measurements (Fig. 4) that Mg2Gd7Zn alloy is characterized by a higher corrosion potential. Zinc increases the corrosion potential of the alloy but the majority of this element is concentrated in intermetallic phases. Although the corrosion potential of this alloy is more positive in comparison with $\mathrm{Mg} 3 \mathrm{Gd}$, the difference between corrosion potentials of solid solution and intermetallic phases with zinc significantly increases the corrosion rate by microgalvanic cell.

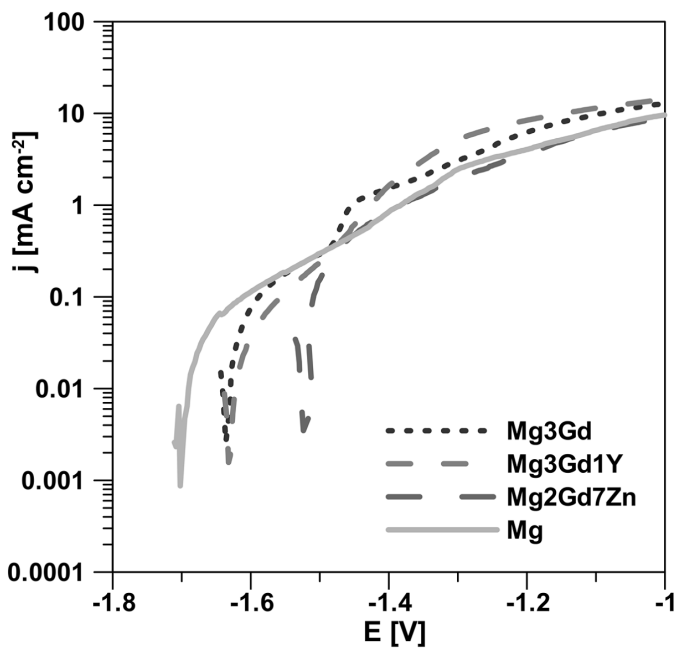

Fig. 4. Potentiodynamic curves of investigated alloys in $9 \mathrm{~g} / 1 \mathrm{NaCl}$ solution. 


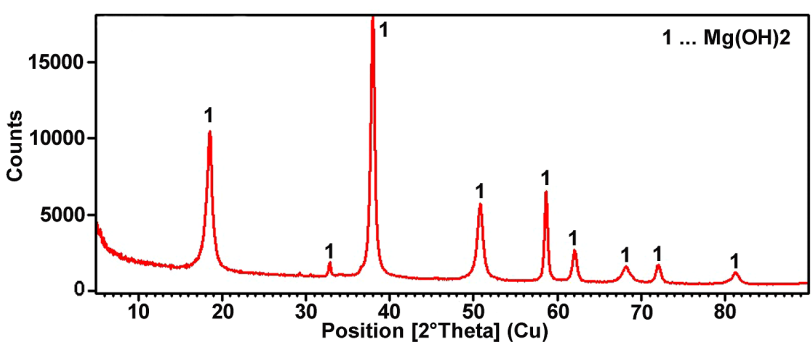

Fig. 5. Diffraction pattern of Mg3Gd binary alloy after an immersion test.
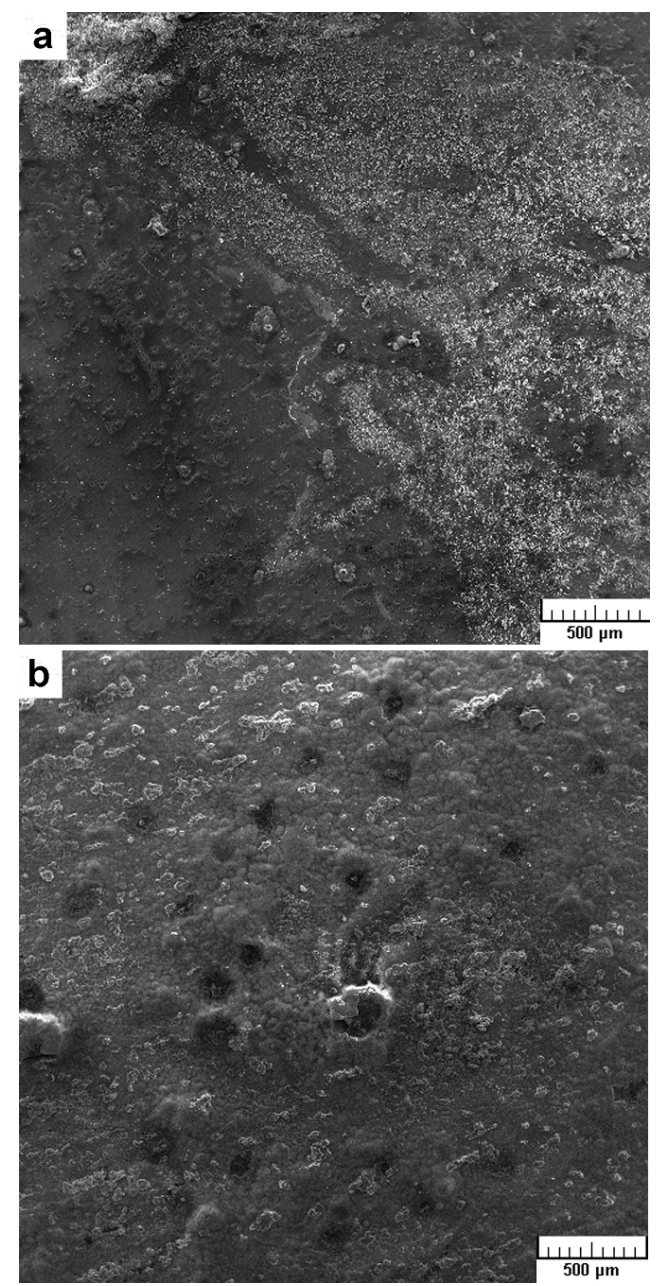

Fig. 6. SEM images of surfaces after exposures in physiological solution (a) Mg3Gd; (b) Mg3Gd1Y.

After corrosion exposures, surfaces of all samples were covered by $\mathrm{Mg}(\mathrm{OH})_{2}$ that was identified by XRD measurements (Fig. 5). However, regular and compact layer was observed only on the surface of Mg3Gd binary alloy (Fig. 6a). Mg3GdY and Mg2Gd7Zn alloys were characterized by irregular disturbed layers with significant pits as a consequence of galvanic corrosion (Fig. 6b).

\section{Conclusion}

The structures of $\mathrm{Mg}-\mathrm{Gd}, \mathrm{Mg}-\mathrm{Y}-\mathrm{Gd}$ and $\mathrm{Mg}-\mathrm{Gd}-\mathrm{Zn}$ alloys were quite inhomogeneous containing dendritic microsegregations and intermetallic phases. The corrosion resistance of investigated alloys was influenced by galvanic cell between solid solution and $\mathrm{Mg}_{5} \mathrm{Gd}$ or $\mathrm{Mg}_{3} \mathrm{GdZn}_{6}$ phases. Compact and protective surface layers of magnesium hydroxide were formed only on the surface of Mg3Gd binary alloy. The remaining alloys significantly suffer from localized corrosion.

\section{Acknowledgments}

This research was financially supported by a specific university research (MSMT No. 21/2011).

\section{References}

[1] C.K. Seal, K. Vince, M.A. Hodgson, IOP Conf. Series: Mater. Sci. Eng. 4, 012011 (2009).

[2] G. Song, Corros. Sci. 49, 1696 (2007).

[3] S. Zhang, , X. Zhang, Ch. Zhao, J. Li, Y. Song, Ch. Xie, H. Tao, Y. Zhang, Y. He, Y. Jiang, Y. Bian, Acta Biomater. 6, 626 (2010).

[4] S. Liang, D. Guan, X. Tan, Mater. Des. 32, 1194 (2011).

[5] L. Gao, R.S. Chen, E.H. Han, J. Mater. Sci. 44, 4443 (2009).

[6] J. Chang, X.W. Guo, S.M. He, P.H. Fu, L.M. Peng, W.J. Ding, Corros. Sci. 1, 166 (2008).

[7] J. Wang, Mater. Sci. Eng. A 456, 78 (2007).

[8] M. Sun, G. Wu, W. Wang, W. Ding, Mater. Sci. Eng. A 523, 145 (2009).

[9] A.A. Nayeb-Hashemi, Phase Diagrams of Binary Magnesium Alloys, ASM International, Metals Park 1998.

[10] E. Zhang, W. He, H. Du, K. Yang, Mater. Sci. Eng. A 488, 102 (2008).

[11] D.K. Xu, W.N. Tang, L. Liu, Y.B. Xu, E.H. Han, J. Alloys Comp. 432, 129 (2007).

[12] K. Liu, J. Zhang, L.L. Rokhlinn, F.M. Elkin, D. Tang, J. Meng, Mater. Sci. Eng. A 505, 13 (2009).

[13] A. Atrens, M. Liu, N.I.Z. Abidin, Mater. Sci. Eng. B 28 (2011), doi:10.1016/j.mseb.2010.12.017. 